\title{
KERAJINAN COR LOGAM ALUMINIUM SEGOROYOSO PLERET BANTUL, DAERAH ISTIMEWA YOGYAKARTA
}

\author{
Timbul Raharjo dan Joko Subiharto
}

\begin{abstract}
The cast aluminum products at Karanggayam, Segoroyoso, Pleret, Bantul is suffering from quality stagnation. They are limited to manufacturing "Vandels", Logos, and Souvenirs as their main products. These products will then be sold to some business around Yogyakarta. The method of manufacturing is still very traditional, Dry casting the aluminum in soft sand. They haven't been able to produce products with certain artistic specifications to supply the global market demand. Thus the need to increase the quality of post-producing techniques like polishing and lathe work is required. These can be achieved by developing the industry in various aspect including but not limited to creation, production, distribution, and management. The 2 targets of this development are 2 home industries: "Habibi Cor" and "Abu Cor". By working on existing technique and skills, compounded by new designs and the application of a polishing machine and a Lathe machine these 2 home industries can be further improved.

The goal of this Program to develop the cast aluminum industry is to accelerate the industry by adding polishing and lathe work, as well as adding a new design like accessories, sculpture, and wall decoration and to increase export by matching the current world trend. After the application of the new technologies and methods, an increase in export is to be expected. which in turn will increase the economic condition of the craftsmen. The methods used are for example: explaining about the uses of this project by socializing the goals, motivation, and the form of the activities itself. Various workshop and guidance programs to give the methods of developing new design, increasing product quality by polishing, and expanding the knowledge about management especially around accounting, producing, and marketing.
\end{abstract}

Key Words: Craft, Cast Aluminum, Segoroyoso

\section{PENDAHULUAN}

Potensi kerajinan cor kuningan dan aluminium di dusun Karanggayam, Segoroyoso, Pleret, Bantul DIY mengalami stagnanisasi karena produk dan teknologinya masih bersifat sederhana. Kebanyakan pengrajin membuat barang yang terbatas dan kecil-kecil, serta kualitas produknya masih kasar, artinya hasilnya dibeli oleh pelanggan masih dalam keadaan belum melalui proses penghalusan $\mathrm{Hal}$ tersebut terjadi dikarenakan para pengrajin belum mampu melakukan proses finishing dengan polish. Selain itu, pengrajin cor logam masih bergantung pada perusahaan pengorder, padahal teknologi pengecoran kuningan dan aluminium wilayah ini memiliki ciri yang khas sebagai produk cor yang dapat disesuaikan dengan selera luar negeri, tinggal bagaimana mengembangkan jenis produk yang sesuai trend desain pasar.

Produk cor logam para pengrajin masih tergolong murah karena added valuenya belum mereka lakukan. Seperti harga souvenir yang rata-rata hanya Rp 10.000,tempat lilin $\mathrm{Rp} 20.000$,- dengan omset kurang lebih $\mathrm{Rp} 30.000 .000$,- dan hal ini masih terbatas jika dibandingkan dengan

\footnotetext{
* Timbul Raharjo (timbulksg@yahoo.com), Joko Subiharto (joko_yk@yahoo.com), Staf Pengajar Jurusan Kriya Fakultas seni Rupa Institut Seni Indonesia Yogyakarta
} 
potensi yang ada. Karena jika dilihat kapasitas produksi yang cukup tinggi dengan nilai omset tersebut, maka secara logika kurang menguntungkan karena marjinnya sangat kecil. Hal ini mengakibatkan perusahaan tidak bisa berkembang secara baik. Padahal saat ini produk cor logam di pasaran internasional mulai berkembang baik, untuk pasar Amerika, Spanyol, dan Korea

Program pengembangan kerajinan cor logam melalui kegiatan Ipteks Bagi Masyarakat (IbM) ini merupakan aplikasi ilmiah untuk meningkatkan pengrajin cor logam Segoroyoso dari sisi kreasi desain, produksi, distribusi, dan manajemennnya. Selain itu juga diterapkan ketrampilan menggunakan satu unit alat polish dan mesin bubut sebagai pancingan dan upaya pengembangan proses produksi sampai pada finishingnya. Hal ini dilakukan sebagai upaya memutus rantai pasar yang dilakukan oleh para tengkulak yang mengambil barang setengah jadi, sebab proses finishingnya berada diluar para pengrajin cor logam Segoroyoso. Melalui program IbM ini diharapkan para pengrajin mendapat keuntungan dengan menambah devisi finishing polish, bubut, serta penambahan desain produk baru terutama yang sesuai dengan konsumen internasional. $\mathrm{Hal}$ tersebut dilakukan dengan strategi pembinaan dan pengembangan, terutama dari sisi sumber daya manusianya. Melalui kegiatan workshop tentang wawasan desain, mendesain produk baru, teknologi polish dan bubut serta cara kerjanya.

Keadaan yang ada pada rumah produksi "Habibi Cor" masih bersifat tradisional terutama alat kowi yang terbuat dari potongan pipa logam, tanah liat untuk membuat cet, dan alat frame cetak, gergaji besi, gerinda, dan oven bakar. Proses produksi dikerj dengan 5 sampai 10 tenaga kerja pada setiap UKM. Umumnya mengerjakan bentuk yang sederhana dengan teknik cetak kering. Cetak kering sering dilakukan karena memiliki kecepatan penggarapan dan dapat diulang tanpa mengganti pasirnya. Kapasitas pengecoran yang dilaksan sehari rata-rata 50 sampai 100 $\mathrm{kg}$, naik turun tergantung dari pesanan yang datang. Bahan kuningan sebagai bahan baku umumnya menggun barang-barang bekas yang banyak dipasok dari pengusaha rongsokan logam, demikian pula bahan aluminium.

Abu cor memiliki 4 tenaga kerja dengan memproduksi barang-barang kuningan untuk peralatan perlengkapan kuda, souvenir, logo, dan lainnya. Abu-cor dipimpin oleh Abu Najah seorang kreatif yang sebelumnya bekerja disebuah perusahaan bidang yang sama di Yogyakarta. Perusahaan ini masih sederhana dilihat dari proses produksi yang dilakukan dengan peralatan yang sederhana pula, kesulitan utama adalah harga produknya yang hanya setengah jadi, UKM ini memerlukan alat produksi untuk menghaluskan yakni mesin poles.

Sedangkan pada UKM "Habibi Cor" lebih cenderung peningkatan dengan mesin bubut sederhana yakni sebuah alat yang dipakai untuk mempercepat produksi membentuk dan finishing terutama produk silindris, mengingat order untuk tempat lilin secara kontinyu berjalan terus, hanya saja proses bubutnya dilakukan ditempat lain sehingga marjin keuntungan yang didapat untuk sebuah produk kurang maksimal. Pengrajin cor ini disamping memerlukan pelatihan dan penerapan alat dengan workshop juga perlu melakukan upaya kerjasama untuk meningkatkan sistem permasarannya. Sehingga antara produksi dan distribusi produk dapat ditingkatkan terutama kerjasama dengan pihak pemerintah untuk memperoleh fasilitasi program pameran.

\section{TINJAUAN SITUASI USAHA}

Kerajinan cor Segoroyoso selama ini hanya memproduksi barang cor yang masih berkualitas relatif rendah, dapat dikat mereka hanya sebagai studio jasa pengecoran. Produk yang dihasilkan pada permukaanya relatif masih kasar, padahal 
produk yang ada dipasaran memiliki tingkat kehalusan tersendiri yang dilakukan dengan pengerjaan lanjutan dengan sistem polish atau selep. Pada produk yang silindris diperlukan presisi produk dengan alat mesin bubut. Dengan penerapan iptek ini terjadi peningkatan 50 persen dari pendapatan biasanya, karena produk yang dihasilkan telah memiliki added value finishing sehingga keuntungan meningkat, tenaga kerja bertambah, dan perusahaan UKM mengalami peningkatan ekonomi.

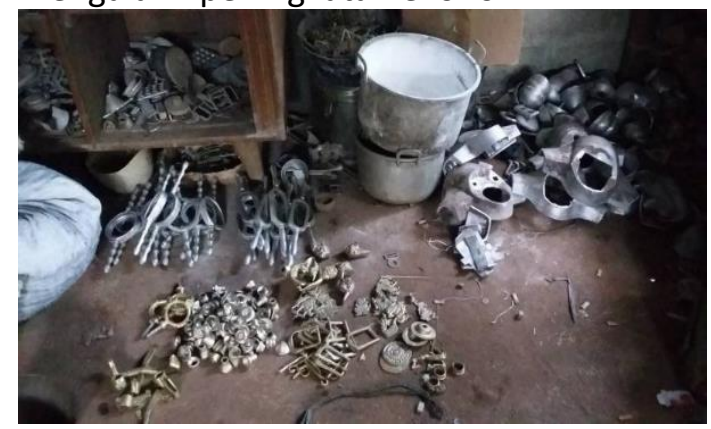

Gambar 1. Gambar produk yang ada dengan karya yang masih kasar

(Foto: Timbul Raharjo)

Penerapan mesin polish dan bubut serta dibarengi dengan workshop cara melakukan proses kerja polish dan membubut, maka didapat produk yang memiliki kualitas finishing yang baik. Alat ini sangat membantu bagi pengrajin karena kendala finishing dengan permukaan halus dapat terselesaikan.

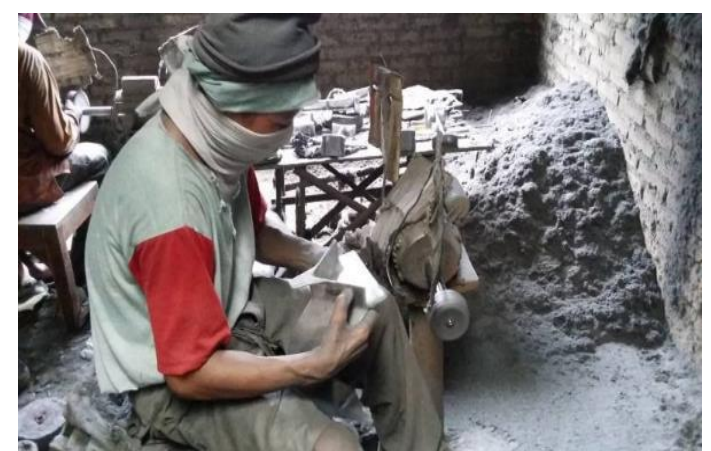

Gambar 2. Alat polish tradisional memiliki tingkat efektivitas untuk mepolis barang kuningan maupun tembaga (Foto: Timbul Raharjo, 2015)

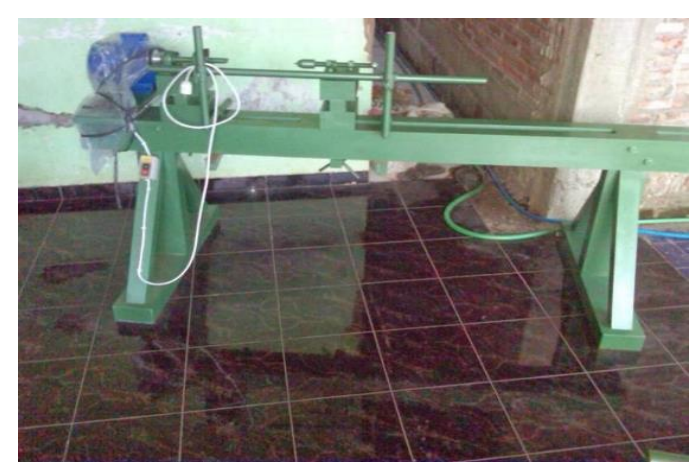

Gambar 3. Mesin bubut, desain ini biasanya untuk pengerjaan kayu, untuk logam lunak seperti aluminium dan kuningan sangat cocok meggun bubut semacam ini pula

(Sumber:https://id.images.search.yahoo.com/images /diunduh tanggal 23 April 2015)

Nilai tambah lain adalah penerapan atau pembinaan tentang desain baru yang sesuai dengan pasar. Pengembangan diseuaikan dengan tingkat produk dan ketrampilan UKM untuk memproduksi desain baru tersebut. Secara estetis jelas terlihat dari desain yang baik dari Jurusan Kriya Institut Seni Indonesia Yogyakarta. Dengan demikian keunggulan produk kompetitif menjadi produk yang memiliki daya saing pasar global.

\section{METODE PELAKSANAAN}

Berikut ini dikemukakan metode pelaksanaan yang dilakukan baik terkait dengan prosedur kerja, kegiatan dan luaran yang diharapkan.

1. Solusi yang ditawarkan

a. Meningkatkan kualitas sumber daya manusia dan produk cor

b. Meningkatkan ketampilan menggun mesin polish/selep dan mesin bubut

c. Desain produk baru yang sesuai dengan trend desain

d. Mengembangkan pasar Nasional dan ekspor untuk produk cor logam.

e. Pengetahuan mengenai manajemen usaha

2. Metode Pendekatan yang ditawarkan

a. Memberikan pengertian dan informasi mengenai kegiatan dan manfaat IbM

b. Pengembangan desain produk cor 
c. Workshop menggun alat tepat guna finishing berupa polish dan bubut

d. Manajemen keuangan, produksi dan pemasaran

3. Prosedur kerja untuk mendukung realisasi metode yang ditawarkan

a. Adanya kemitraan di antara para pengrajin, yang kemudian bergerak dengan sistem klaster. Kemitraan dikembangkan pula dengan para konsumen yang notabene memiliki link pasar tersendiri sehingga terjadi kerjasama yang baik dan saling menguntungkan.

b. Kerjasama dengan Dinas perindustrian Kabupaten Bantul, perdagangan, dan pihak perguruan tinggi.

4. Luaran dan manfaat yang dihasilkan

a. Memberi pembelajaran pada pengrajin untuk merubah mindset agar anggapan yang selama ini dianggap puas dengan produk yang dihasilkan, mau berubah untuk melakukan upaya peningkatan dalam mengenbangkan UKM.

b. Meningkatkan ketampilan perajin untuk melakukan finishing polish dan bubut.

c. Meningkatkan distribusi dan pemasaran

d. Meningkatkan nilai jual produk cor

\section{PEMBAHASAN}

Pada tahap awal kegiatan ini sosialisasi kepada UMKM, untuk memberikan pemahaman tentang IbM, program-program yang dilaksanakan, serta tujuan dan manfaat dari IbM. Sosialisasi juga dimaksudkan untuk meneguhkan kembali komitmen kerjasama yang sudah pernah dibicar dan dituangkan dalam proposal IbM. Pada kegiatan ini pengrajin/UMKM juga diberikan kesempatan juga untuk memberikan masukan kembali tentang permasalahan-permasalahan yang dihadapi, dan juga menyampaikan pendapat apakah program kegiatan yang telah disusun oleh

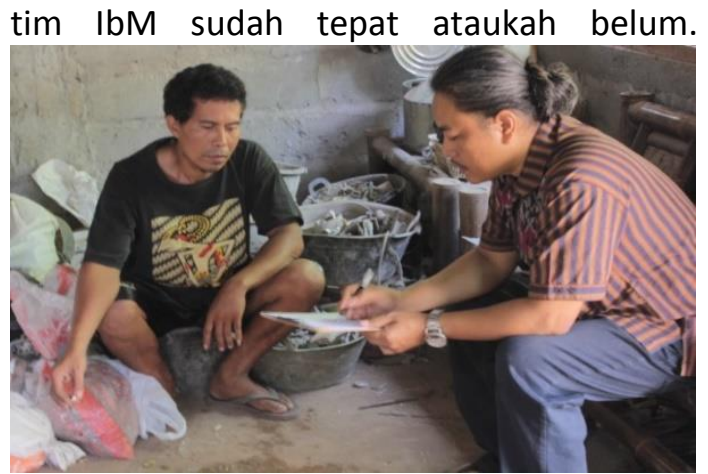

Gambar 4. Sosialisasi Tim IbM dengan pemilik "Abu Cor" (Foto : Joko Subiharto, 2016)

Dampak sosial atas perkembangan UKM cor kuningan dan aluminium adalah dengan adanya peningkatan produksi, maka serapan tenaga kerja makin tinggi, sehingga memberikan kesejahteraan masyarakat disekitarnya. Selain itu pengembangan model IbM ini dapat diterapkan pada industri-industri lain yang sejenis atau paling tidak adanya indikasi peningkatan kreativitas, produktivitas, dan market. Produk yang dihasilkan memiliki kualitas yang baik karena adanya perbaikan finishing sehingga pasar nasional menerima sebagai barang kebanggaan produk dalam negeri yang memiliki kualitas baik. Demikian juga pasar ekspor dengan adanya peningkatan ekpor dari komoditas ini sudah barang tentu juga meningkatkan devisa Negara melalui ekspor kerajinan cor kuningan dan aluminium ini.

Program Ipteks bagi masyarakat (IbM) kerajinan Cor Logam di Segoroyoso ini diharapkan dapat meningkatkan usaha produksi yang masih dalam taraf sederhana dan tradisional menjadi usaha produksi yang kreatif dan inovatif, sehingga meningkat kuantitas maupun kualitas produksinya. Adapun target luaran yang diharapkan dari program IbM ini adalah, penguasaan teknologi tepat guna untuk peningkatan kemampuan dan ketrampilan pengrajin dalam segi desain, teknik produksi. Dengan meningkatnya ketrampilan para pengrajin meningkatkan produksi yang dihasilkan, baik secara kuantitatif maupun kualitatif. Selain itu juga memiliki target luaran berupa 
desain/produk kerajinan dalam berbagai jenis dan bentuk. Peningkatan secara kuantitatif ditargetkan dapat mencapai $30 \%$ dari jenis produk yang dibuat sekarang, serta $25 \%$ s.d $50 \%$ dari kapasitas produksi sekarang. Peningkatan kualitas ditargetkan menghasilkan barang yang memiliki presisi dalam ukuran, kehalusan dalam pembentukan dan finishing.

Terciptanya produk barang-barang souvenir atau produk kerajinan logam dengan desain-desain baru yang kreatif, inovatif, dan unik, sehingga memiliki ciri khas tersendiri. Tercipta 5 sampai 10 model produk dengan desain-desain baru dari produk yang belum ada. Jadi jika ditargetkan 5 jenis produk, berarti terdapat 10 model produk, dari kedua UKM. Sebuah peningkatan desain yang cukup variatif untuk menambah jenis produk yang telah ada. Pasca program ini dilaksanakan, para peserta memiliki kemampuan memproduksi kerajinan bambu batik dengan teknologi tepat guna yang memiliki kekhasan tersendiri dengan kualitas yang baik. Peserta juga memiliki kemampuan manajerial untuk mengelola usahanya. Karena para peserta dibekali juga dengan pengetahuan manajemen, baik keuangan, produksi maupun pemasaran.

Saat kegiatan sosialisasi juga diberikan motivasi kepada pengrajin/UMKM agar tidak cepat berpuas diri dengan apa yang telah ada saat ini. UMKM terus didorong untuk memiliki semangat untuk kreatif dan inovatif meningkatkan usahanya sehingga dapat berkembang terus dari waktu ke waktu. Perkembangan usaha hanya dapat diraih dari usaha dan kerja keras dari pengrajin. Kunci kesuksesan usaha terletak pada diri pengrajin sendiri. Pihak lain, seperti tim IbM hanyalah sebagai fasilitator saja untuk membantu pengrajin belajar tentang hal-hal baru guna mengatasi permasalahan-permasalahan usaha yang dihadapi.

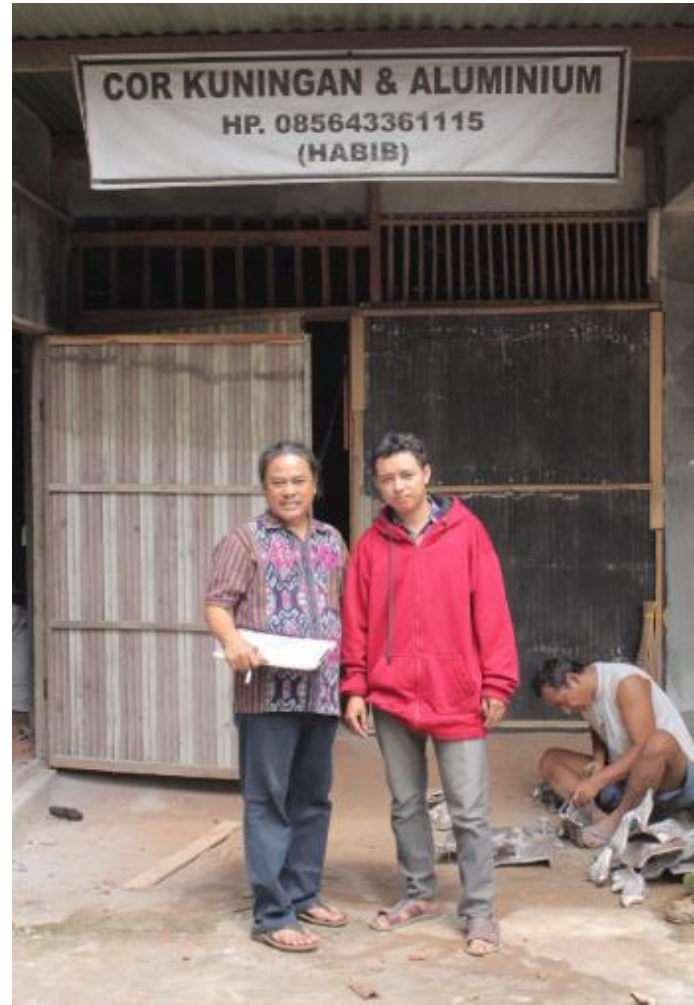

Gambar 5. Ketua Tim IbM setelah acara sosialisasi bersama pemilik UMKM Habib Cor

(Foto : Joko Subiharto, 2016)

Kegiatan atau program IbM yang dilaksan ada yang hanya melibatkan pemilik/pimpinan saja, namun juga ada beberapa kegiatan yang melibatkan tenaga produksi pada UMKM yang bersangkutan. Oleh karena itu, pada kegiatan sosialisasi ini juga dilakukan kesepakatan mengenai hari dan waktu/jam kegiatan, sehingga tidak menggganggu produksi harian pengrajin/UMKM.

Kegiatan ini menjadi salah satu program yang diberikan kepada UMKM, dengan dasar bahwa produk kerajinan adalah bagian dari sektor usaha kreatif, sehingga pengembangan produk-produk baru yang lebih bervariasi menjadi suatu keharusan dan kebutuhan bagi UMKM. Desain-desain produk kerajinan berkembang dan berubah dengan cepat, dibandingkan produk-produk non kerajinan. Jika pengrajin atau UMKM kerajinan produk-produknya monoton dan tidak cepat mengikuti perkembangan, maka ditinggal oleh konsumennya. 
Pada kegiatan pengembangan desain, desain dihasilkan melalui dua cara:

1. Desain dari pengembangan produk yang sudah ada, baik dari segi ukuran, bentuk, fungsi dan finishing. Hasil dari cara pertama ini juga untuk mengevaluasi dan memperbaiki produk yang telah ada.

2. Selain memperbaiki desain yang telah ada, pada kegiatan ini juga diberikan desain-desain baru yang sesuai dengan perkembangan trend desain dan selera konsumen.

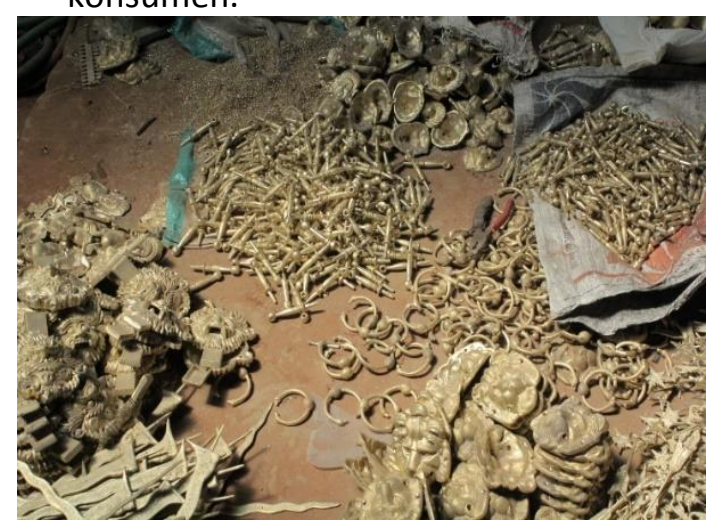

Gambar 6. Produk-produk dari UMKM "Abu Cor" (Foto : Joko Subiharto, 2016)

Pada kegiatan pengembangan desain, kegiatan yang dilakukan berbentuk pendampingan, karena tahapan yang dilakukan mem waktu yang panjang. Pada tahap awal bersama pengrajin dilakukan studi awal untuk mengidentifikasikan desain produk yang telah ada, setelah terakhir adalah pembuatan prototipe hasil dari perancangan ulang.itu dilakukan perancangan ulang (redesain), dan

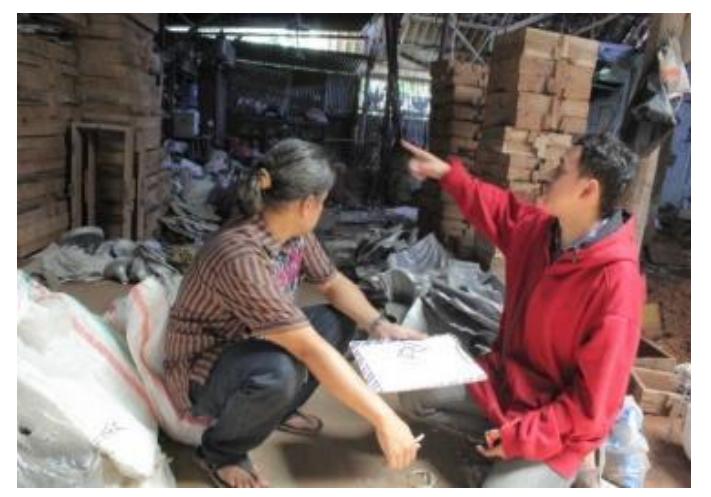

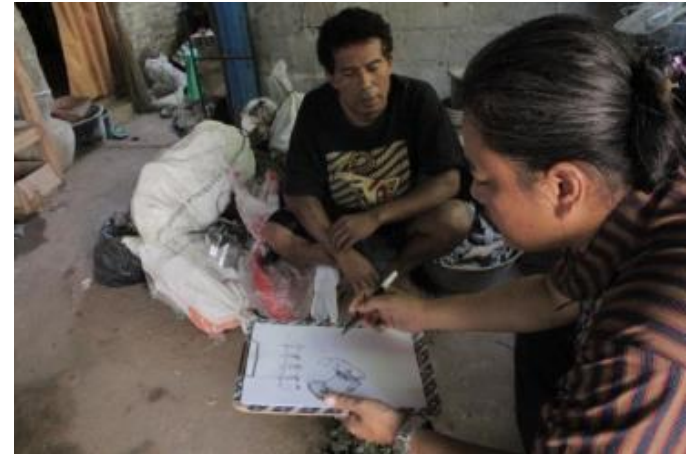

Gambar 7. Identifikasi dan Redesain produk bersama pengrajin

(Foto : Joko Subiharto, 2016)

Selain redesain produk-produk lama, dibuat pula desain-desain baru hasil dari identifikasi trend desain dan selera konsumen. Eksplorasi trend desain didapatkan dari pameran kerajinan, majalah, dan internet. Data-data tersebut dikumpulkan sebagai sumber ide untuk perancangan desain baru untuk memperbanyak variasi produk kerajinan logam dari UMKM.

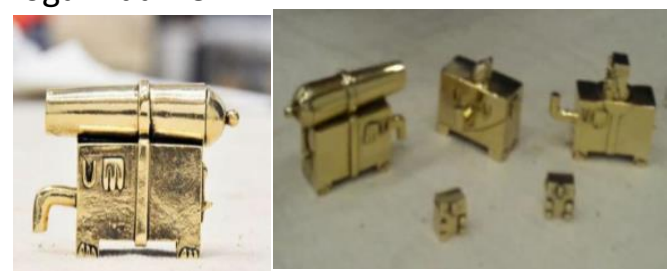

Gambar 8. Figur Miniatur oleh Amanda Visell

(Sumber : www.trendhunter.com, 12/4/2016)

Berdasarkan trend desain yang berkembang, seperti gambar 9 diprediksi bahwa pemilik rumah semakin mencari produk-produk untuk personalisasi ruang mereka salah satunya dengan dekorasidekorasi yang terinspirasi dari seni patung.

Berikut ini beberapa desain baru untuk pengembangan produk baru bagi UMKM: 
a) Desain Pertama

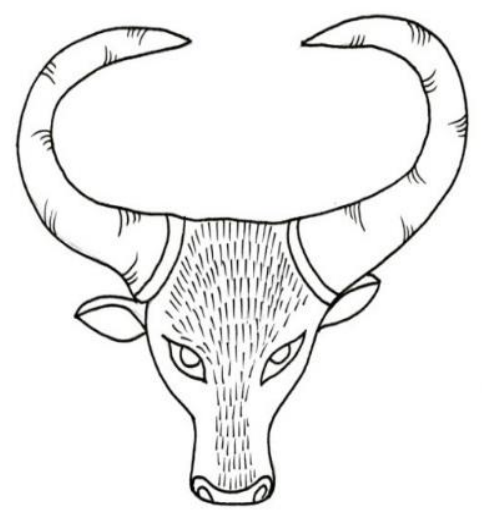

Gambar 9. Desain Wall Decor 1

(Sketsa : Timbul Raharjo, 2016)

b) Desain Kedua

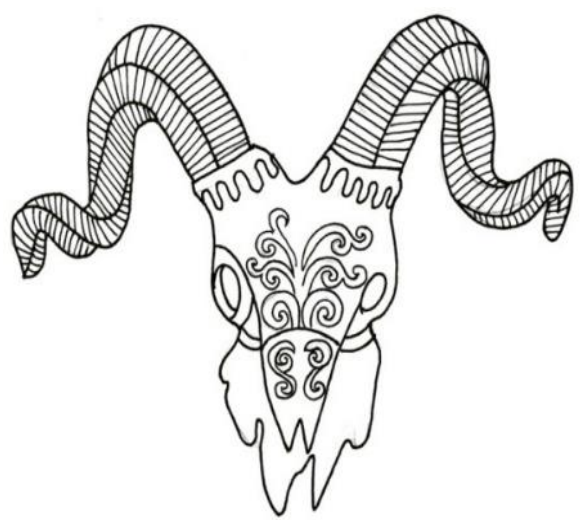

Gambar 10. Desain Wall Decor 2

(Sketsa : Timbul Raharjo, 2016)

c) Desain Ketiga

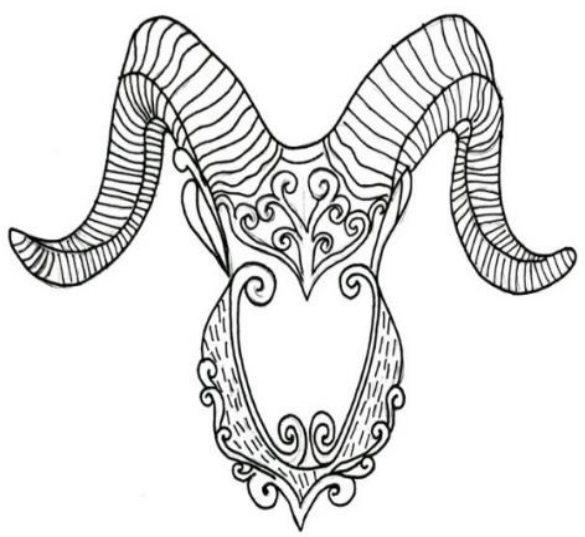

Gambar 11. Desain Wall Decor 3

(Sketsa : Timbul Raharjo, 2016) d) Desain Keempat

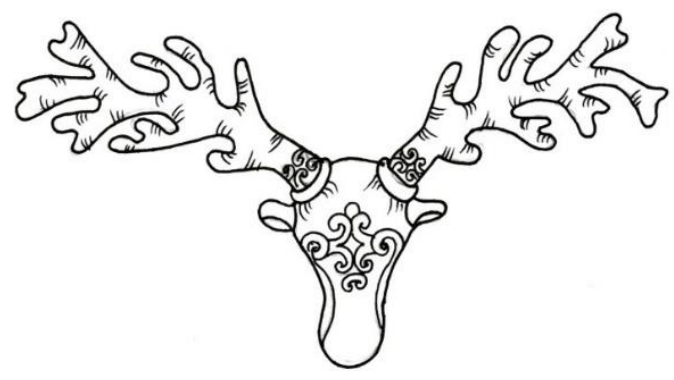

Gambar 12. Desain Wall Decor 4

(Sketsa : Timbul Raharjo, 2016)

e) Desain Kelima

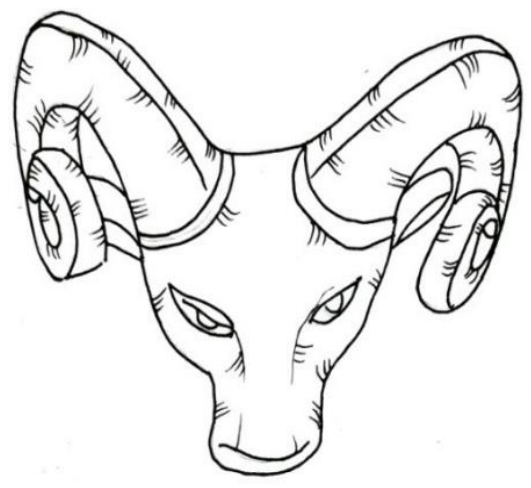

Gambar 13. Desain Wall Decor 5

(Sketsa : Timbul Raharjo, 2016)

f) Desain Keenam

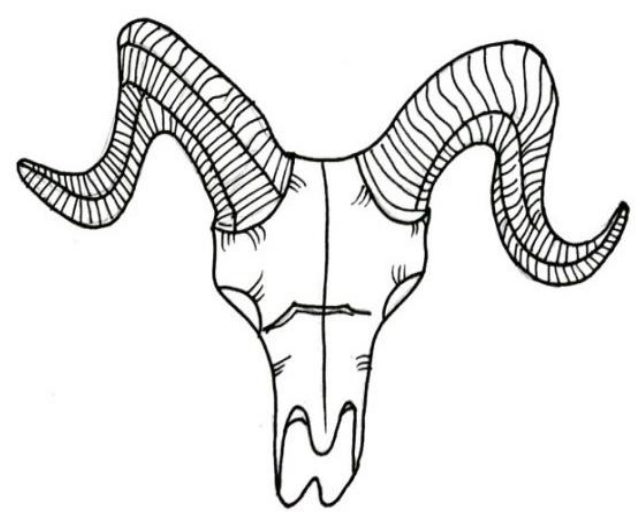

Gambar 14. Desain Wall Decor 6

(Sketsa : Timbul Raharjo, 2016) 
g) Desain Ketujuh

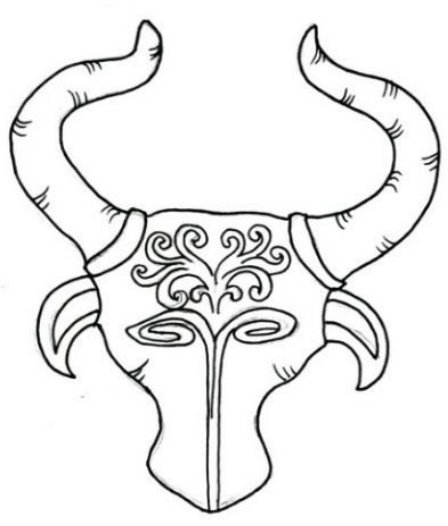

Gambar 15. Desain Wall Decor 7 (Sketsa : Timbul Raharjo, 2016)

h) Desain Kedelapan

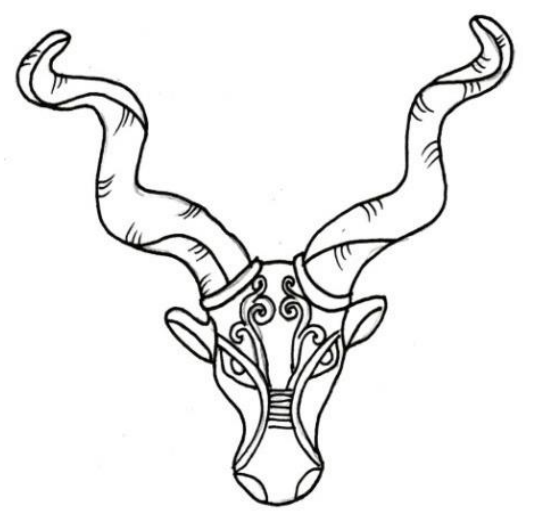

Gambar 16. Desain Wall Decor 8

(Sketsa : Timbul Raharjo, 2016)

i) Desain Kesembilan

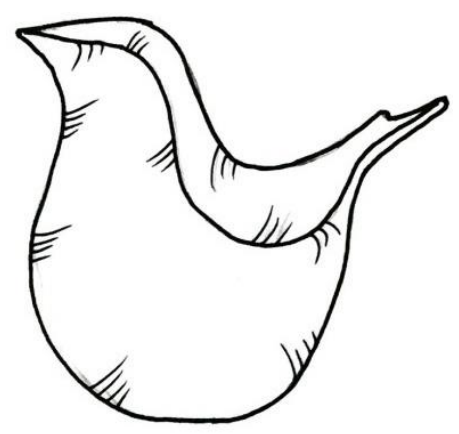

Gambar 17. Desain Table Decor 1 (Sketsa : Timbul Raharjo, 2016) j) Desain Kesepuluh

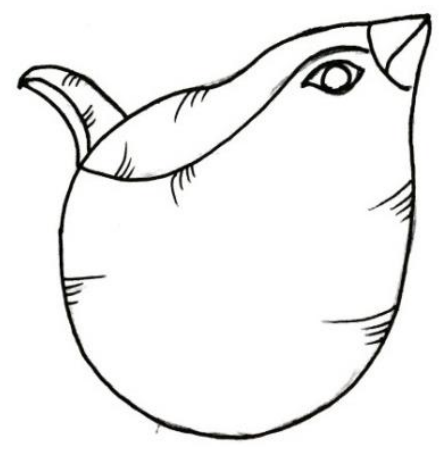

Gambar 18. Desain Table Decor 2

(Sketsa : Timbul Raharjo, 2016)

Langkah selanjutnya adalah melakukan pelatihan dan pendampingan untuk merealisasikan atau memproduksi desain yang telah dibuat. Pada kegiatan ini juga diberikan pelatihan alat untuk polish dan bubut logam. Kegiatan ini dilaksanakan dengan tujuan untuk menambah varian produk dan meningkatkan kualitas produk, terutama dari sisi finishing produk.
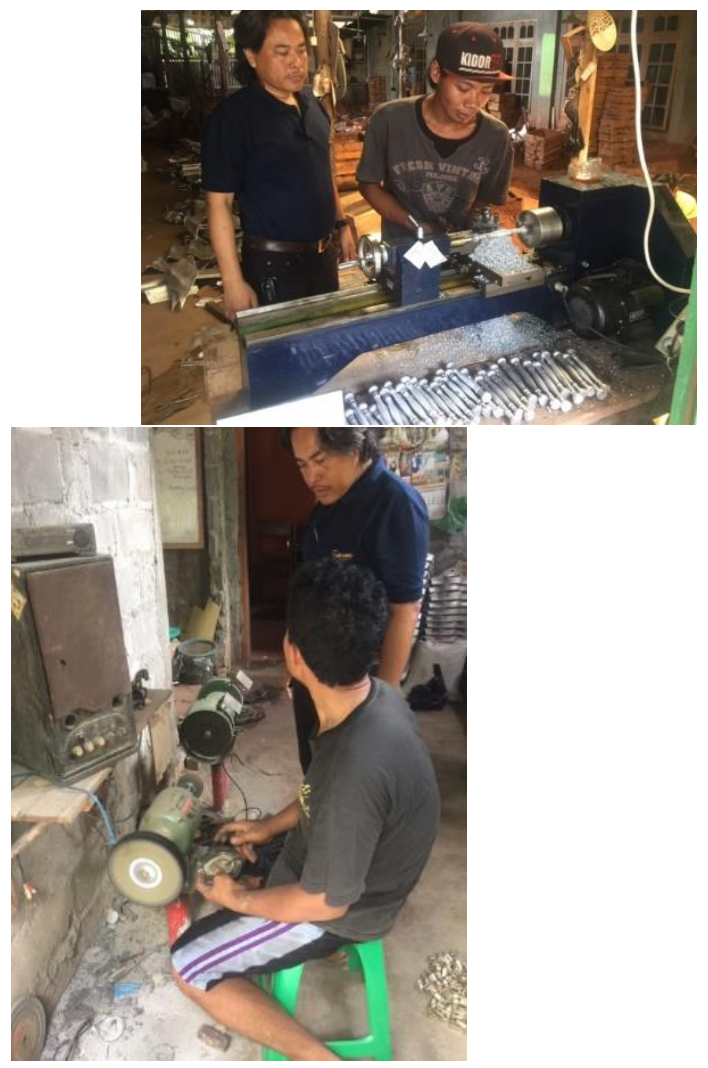

Gambar 19. Pelatihan bubut dan polish (Foto : Joko Subiharto, 2016) 
Desain-desain produk baru juga diuji cobakan untuk diproduksi, menggunakan metode pencetakan sesuai dengan yang telah dikuasai oleh pengrajin, dengan didampingi oleh pembina.

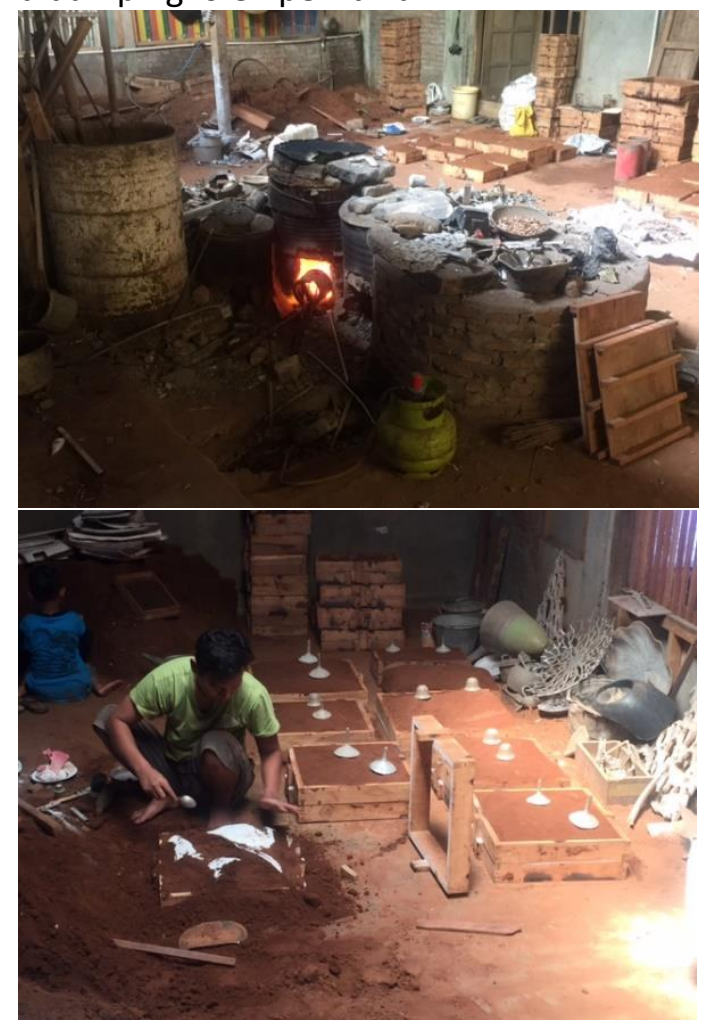

Gambar 20. Proses Produksi Desain Baru

(Foto : Joko Subiharto, 2016)

Produk baru hasil dari pengembangan desain, dengan jumlah 10 buah dapat dilihat pada gambar di bawah.

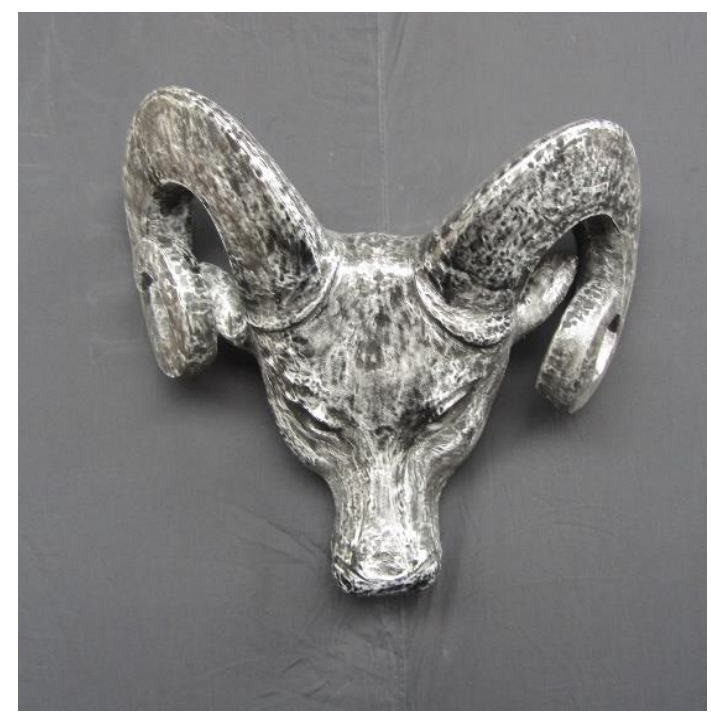

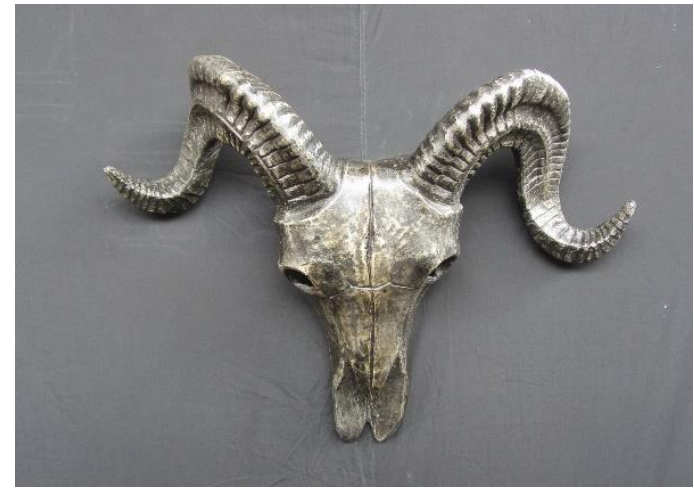

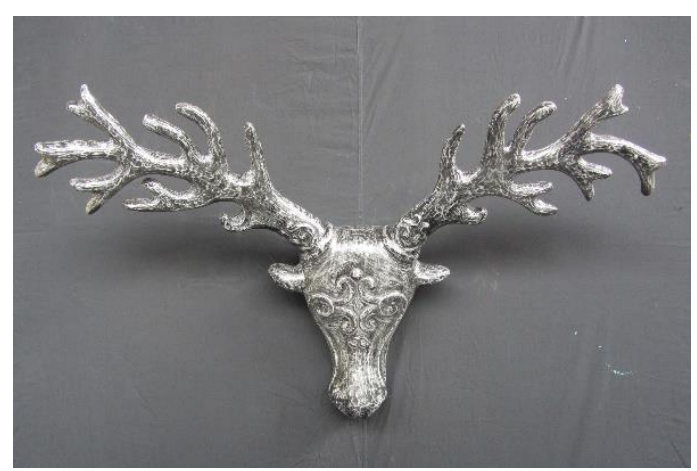

Gambar 21. Produk baru 1

(Foto : Joko Subiharto, 2016)
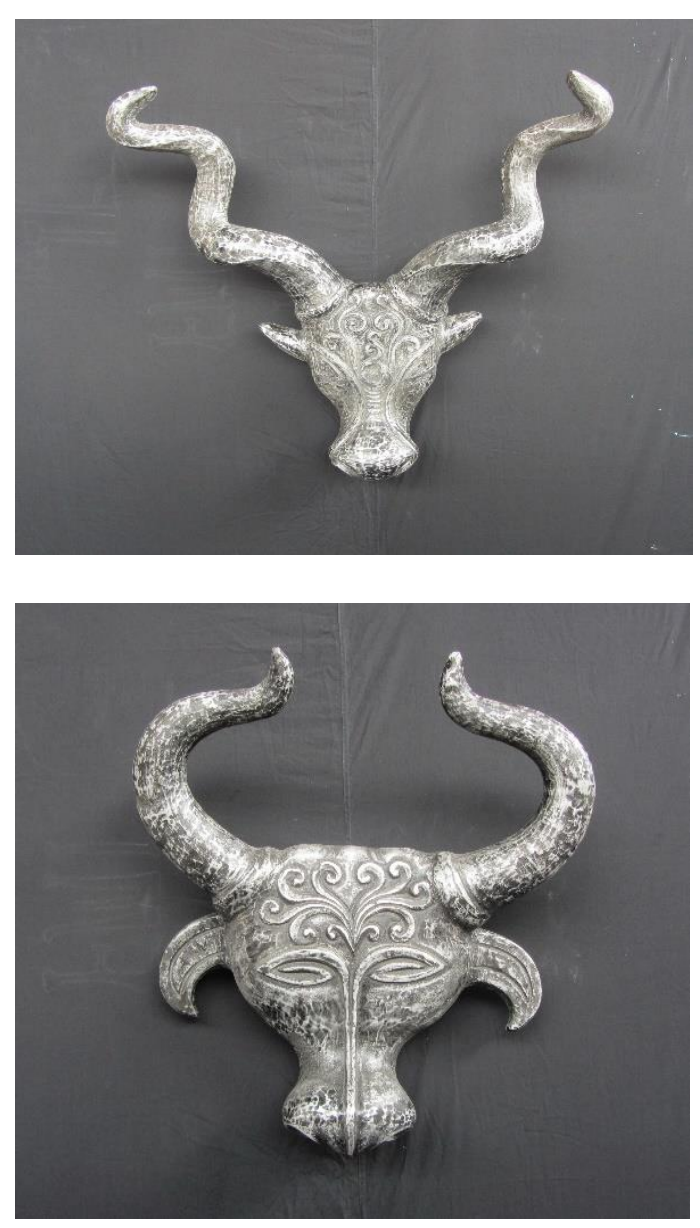


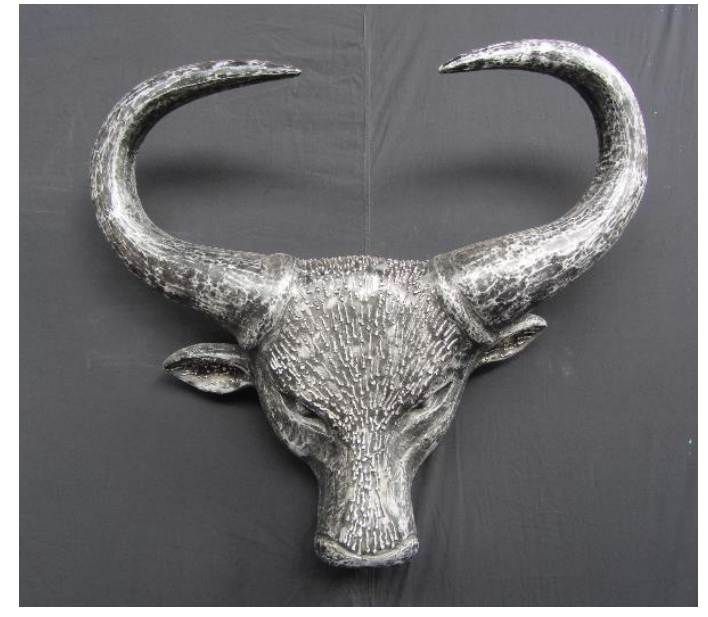

Gambar 22. Produk baru 2

(Foto : Joko Subiharto, 2016)
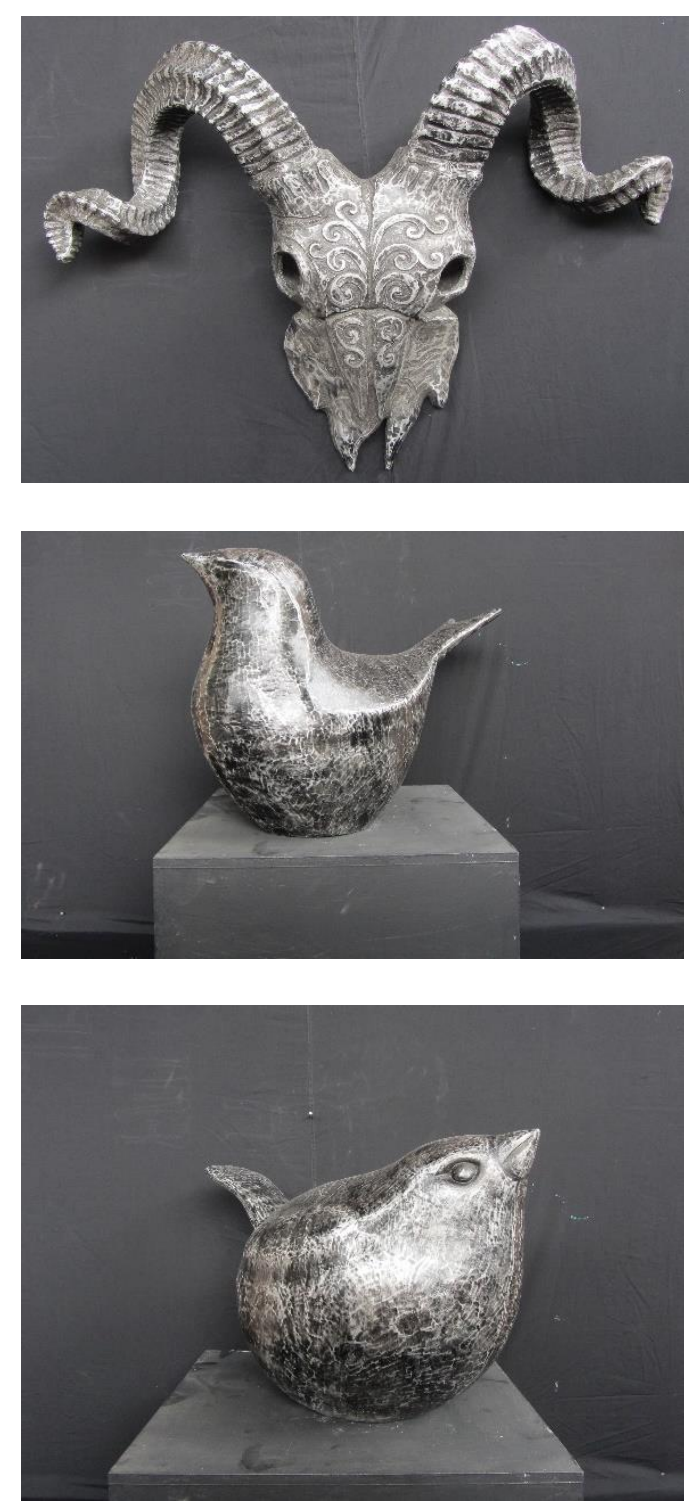

Gambar 23. Produk baru 3

(Foto : Joko Subiharto, 2016)

\section{KESIMPULAN}

Berdasarkan hasil dari kegiatan, dapat disimpulkan hal-hal berikut:

1. Produk pengrajin/UMKM masih monoton dan belum bervariasi, sehingga kurang dapat mengikuti perkembanganm tren dan selera konsumen.

2. Kualitas produk masih belum baik, terutama terkait dengan finishing produk yang masih cenderung apa adanya, sehingga akan mempengaruhi pula dalam penentuan harga.

3. Bahwa trend desain yang berkembang di dunia dapat dipelajari dari berbagai macam informasi yang bersumber dari perubahan mode dunia yang diciptakan oleh desainer, arsitektur, asesoris interior/eksterior dan lain-lain yang dapat dipejari dari buku, majalah, internet.

4. Berdasarkan eksplorasi peneliti terhadap trend dunia, dapat dirumuskan beberapa desain yang dapat dikembangkan melalui produk cor logam dari UMKM, khususnya untuk dekorasi rumah.

5. Dengan eksplorasi penciptaan desain berdasarkan prediksi trend yang akan berkembang di pasar maka diharapkan produk yang akan dibuat akan dapat diterima pasar dengan lebih baik.

6. Pengembangan desain baru sebanyak 10 buah yang kemudian diproduksi menjadi produk prototipe.

7. Pengembangan dan peningkatan kualitas produksi dilakukan dengan menerapkan finishing yang baik dengan alat bubut dan mesin polish.

\section{B. Saran}

1. Dalam penciptaan produk yang akan dipasarkan baik lokal maupun internasional sebaiknya menggunakan pemahaman korelasi antara proses kreatifitas dengan membaca trend desain, pertimbangan reproduksi dan distribusi produk.

2. Desain ini dapat diterapkan sebagai produk dalam uji coba pasar. 


\section{DAFTAR PUSTAKA}

Brown, Lisa. (2000) Metalcraft for the home, North Light Books, Cincinati Ohio

Daryanto, 1999, Teknik Pesawat Tenaga, Departemen Pendidikan dan Kebudayaan, PPPGT/VEDC, Bumi Aksara, Malang.

Prasetyowibowo, Bagas. (1998) Desain Produk Industri, Yayasan Delapan Sepuluh, Bandung

Raharjo, Timbul, 1991, “Teknik Produksi Kriya logam: Mengukir, Menyambung, dan Menempa Logam", Jurusan Kriya Fakultas Seni Rupa dan Desain ISI Yogyakarta.

Sachari, Agus. (1986) Seni, Desain, dan Teknologi, Pustaka, Bandung

Sunaryo, S.Hudi dan A. Sri Bandono (1979), Pengetahuan Teknologi Kerajinan Logam 1, Departemen Pendidikan dan Kebudayaan, Jakarta

Surdia, Tata dan Chijiwa, Kenji, 2012, Teknik Pengecoran Logam, PT. Balai Pustaka, Jakarta.

Untracht, Oppi (1968), Metal Technique for Craftsmen, Dubledey and Company, New York

Wiryosumarto, Harsono dan Okumura, Toshie, 2008, Teknologi Pengelasan Logam, Paramitha, Jakarta. 